Supplementary Material for.....

\title{
Chiral Shift Reagent for Amino Acids Based on Resonance Assisted Hydrogen Bonding
}

Jik Chin,${ }^{*}{ }^{\dagger}$ Dong Chan Kim, ${ }^{\ddagger}$ Francis Panosyan, ${ }^{\dagger}$ Kwan Mook Kim ${ }^{*}$,

(1)<smiles>Oc1ccc2ccccc2c1-c1c(O)ccc2ccccc12</smiles>

$2.2 \mathrm{ClCH}_{2} \mathrm{OCH}_{3}$

$\mathrm{DMF} / 2.4 \mathrm{NaH}$ $>95 \%$ yield<smiles>COCOc1ccc2ccccc2c1-c1c(OC)ccc2ccccc12</smiles>

A

(2)
A $\quad \frac{\mathrm{THF} /-78^{\circ} \mathrm{C} / 1 \mathrm{hr}}{1.2 \mathrm{n}-\mathrm{BuLi}}$<smiles>CCCCCC(C)C</smiles><smiles>COCOc1cc2ccccc2c(-c2c(OC)ccc3ccccc23)c1OC</smiles>

(3)

B $\quad \frac{70^{\circ} \mathrm{C} / 30 \mathrm{~min} .}{\mathrm{EtOH} / \mathrm{HCl}}$<smiles>O=Cc1cc2ccccc2c(-c2c(O)ccc3ccccc23)c1O</smiles>

B

$65 \%$ yield $98 \%$ yield<smiles>O=Cc1cc2ccccc2c(-c2c(OC(=O)c3ccc([N+](=O)[O-])cc3)ccc3ccccc23)c1O</smiles> 


\section{Experimental Procedure}

(1) Synthesis of MOM protected binol (A): NaH (1.92 g, $80 \mathrm{mmol})$ was added to DMF ( $30 \mathrm{ml})$ on ice bath. Binol ((R)-(+)-1,1'-bi-2-naphthol) $(10 \mathrm{~g}, 34 \mathrm{mmol})$ in DMF (50 ml) was dropped to this solution for $20 \mathrm{mim}$. After $30 \mathrm{~min}$, mom chloride $(6.4 \mathrm{~g}, 80 \mathrm{mmol})$ was dropped to this solution for $20 \mathrm{~min}$. The reaction was monitored by TLC. After $1 \mathrm{hr}$ stirring, mom protected binol A was isolated from the organic layer by extraction of the reaction mixture with chloroform and water. The product $\mathbf{A}$ was further purified by silica column chromatography with a hexane and EA 5:1 mixture. Yield $95 \%$.

(2) Synthesis of MOM protected binol aldehyde (B): n-BuLi 2.5 M solution in hexanes $(9.7 \mathrm{ml}, 24 \mathrm{mmol})$ was dropped to the solution of mom protected binol $(7.4 \mathrm{~g}, 20 \mathrm{mmol})$ in THF $(50 \mathrm{ml})$ on dry-ice/acetone bath. After $1 \mathrm{hr}$ stirring, DMF (1.6 g, $22 \mathrm{mmol}$ ) was dropped to the solution. The temperature of the reaction mixture was raised to $-40{ }^{\circ} \mathrm{C}$. After $3 \mathrm{hrs}$ stirring, the reaction was quenched by saturated an ammomium chloride solution and the products were extracted by chloroform. $4.4 \mathrm{~g}$ of the product $\mathbf{B}$ was isolated by column chromatography with a hexane and EA 5:1 mixture. Yield: $65 \%$.

(3) Deprotection of $\mathbf{B}: \mathrm{HCl}(35 \%, 3 \mathrm{ml}, 30 \mathrm{mmol})$ was added to $\mathbf{B}(4.4 \mathrm{~g}, 11$ $\mathrm{mmol}$ ) in ethanol and the solution was heated to $70{ }^{\circ} \mathrm{C}$ for $10 \mathrm{~min}$. The solution was evaporated to dryness and the product was purified by column chromatography with a hexane and EA 5:1 mixture. Yield: $98 \%$.

(4) Synthesis of benzoyl-binol aldehyde (2): Benzoyl chloride (0.16 g, $1.1 \mathrm{mmol})$ in THF (5 ml) was dropped to $\mathbf{B}(0.31 \mathrm{~g}, 1.0 \mathrm{mmol})$ in THF $(10 \mathrm{ml})$ on ice bath. After $1 \mathrm{hr}$ stirring, the reaction mixture was extracted by chloroform and water. The products in organic layer were separated by column chromatography with a hexane and EA 5:1 mixture. 0. $25 \mathrm{~g}$ of 2 was obtained. Yield: $61 \%$. 2: ${ }^{1} \mathrm{H}$ NMR $\left(\mathrm{CDCl}_{3}, 300 \mathrm{MHz}\right) \delta 10.54(\mathrm{~s}, 1 \mathrm{H},-\mathrm{OH}), 10.14(\mathrm{~s}, 1 \mathrm{H},-\mathrm{CHO}), 8.68(\mathrm{~s}$, $1 \mathrm{H}), 7.1-8.1(\mathrm{~m}, 15 \mathrm{H}) ;{ }^{13} \mathrm{C} \mathrm{NMR}\left(\mathrm{CDCl}_{3}, 70 \mathrm{MHz}\right) \delta 196.5,164.5,153.6$, 147.3, 138.3, 137.5, 133.3, 133.2, 131.9 - 116.8; HRMS calcd for $\mathrm{C}_{28} \mathrm{H}_{19} \mathrm{O}_{4}[\mathrm{M}$ $+\mathrm{H}]^{+} 419.1283$, found 419.1283 .

(5) Synthesis of para-nitrobenzoyl-binol aldehyde (3): 3 was obtained following the same procedure described in (4) using para-nitrobenzoyl chloride instead of benzoyl chloride. Yield: $56 \%$. 3: ${ }^{1} \mathrm{H}$ NMR $\left(\mathrm{CDCl}_{3}, 300 \mathrm{MHz}\right) \delta 10.57(\mathrm{~s}, 1 \mathrm{H}$, $-\mathrm{OH}), 10.13(\mathrm{~s}, 1 \mathrm{H},-\mathrm{CHO}), 8.27(\mathrm{~s}, 1 \mathrm{H}), 7.0-8.2(\mathrm{~m}, 14 \mathrm{H}) ;{ }^{13} \mathrm{C} \mathrm{NMR}\left(\mathrm{CDCl}_{3}, 70\right.$ $\mathrm{MHz}) \delta 196.5,162.7,153.5,150.5,146.8,138.4,137.2,134.6133 .1$ - 116.4; HRMS calcd for $\mathrm{C}_{28} \mathrm{H}_{18} \mathrm{NO}_{6}[\mathrm{M}+\mathrm{H}]^{+} 464.1130$, found 464.1131 . 
Rate of imine formation was followed by UV/Vis methods. In a typical experiment, the rate of imine formation between $3(0.1 \mathrm{mM})$ and alanine $(20 \mathrm{mM})$ was monitored by following the increase in visible absorption at $460 \mathrm{~nm}$ at $25 \mathrm{C}$ (Figure S1). Pseudo first order rate constant $\left(\mathrm{k}=6.9 \times 10^{-2} \mathrm{~s}^{-1}\right)$ was obtained by fitting the plot according to a first order equation.

kinetics of imine formation

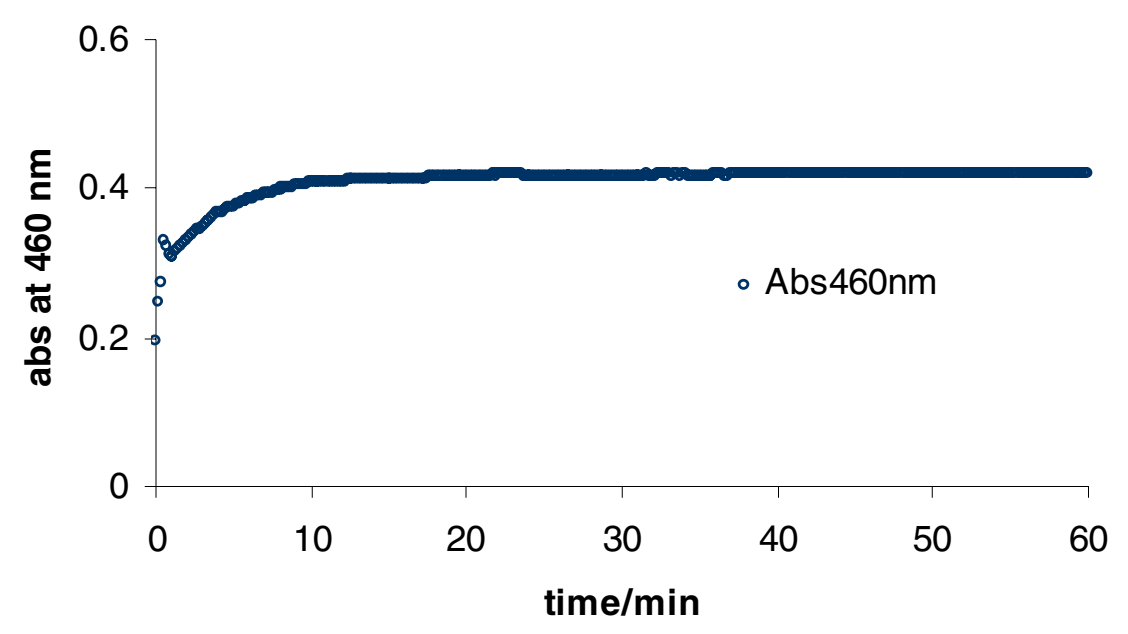

